\title{
Effects of $\mathrm{LH}$, prostaglandin $\mathrm{E}_{2}, 8$-bromo-cyclic AMP and forskolin on progesterone secretion by pig luteal cells
}

\author{
S-M. Feng and G. W. Almond* \\ Department of Food Animal and Equine Medicine, College of Veterinary Medicine, North Carolina State \\ University, Raleigh, NC 27606, USA
}

\begin{abstract}
The present study examined the effects of $\mathrm{LH}$, prostaglandin $\mathrm{E}_{2}\left(\mathrm{PGE}_{2}\right), 8$-bromo-cyclic AMP (cAMP) and forskolin on progesterone secretion by small and large pig luteal cells. Corpora lutea were isolated from gilts ( $n \geq 3$ per day) on days 9,12 and 14 of the oestrous cycle and days $9,12,14$ and 30 of pregnancy. After enzymatic dissociation of the corpora lutea, small and large luteal cells were obtained by elutriation. Culture plates (24-well) were then seeded with 150000 small luteal cells or 30000 large luteal cells per well in $1 \mathrm{ml}$ M199 medium in the absence or presence of LH, PGE 2, LH plus PGE , $^{\prime}$-bromo-cAMP or forskolin. After $12 \mathrm{~h}$ of incubation, culture plates were centrifuged, and the supernatant collected and frozen for subsequent assay of progesterone. Differences within day were not detected between cyclic and pregnant gilts, and thus, results were combined for days 9,12 and 14. Basal progesterone secretion by small luteal cells was less $(P<0.05)$ on days 14 and 30 than days 9 and 12 . Treatment with $\mathrm{LH}, \mathrm{PGE}_{2}, 8$-bromo-cAMP or forskolin increased $(P<0.05)$ progesterone secretion by small luteal cells on days 9 and 12 ; however, treatments had no effect on days 14 and 30 . Basal progesterone production by large luteal cells was less $(P<0.05)$ on day 30 compared with other days. $\mathrm{PGE}_{2}$ stimulated $(P<0.001)$ progesterone production by large luteal cells at all days. In contrast, 8-bromo-cAMP and forskolin inhibited progesterone production by large luteal cells on day $12(P<0.05)$, and day $14(P<0.001)$. These data show that pregnancy status does not alter luteal cell response to the aforementioned secretagogues. However, regulation of progesterone secretion differs between small and large luteal cells, and the age of the corpora lutea. Also, it is unlikely that the stimulatory actions of $\mathrm{PGE}_{2}$ involve increased cAMP production in pig large luteal cells.
\end{abstract}

\section{Introduction}

Prostaglandin $\mathrm{F}_{2 u}\left(\mathrm{PGF}_{2 u}\right)$ is recognized for its luteolytic actions in pig corpora lutea. In contrast, the role of prostaglandin $E_{2}$ $\left(\mathrm{PGE}_{2}\right)$ in corpus luteum function has received limited attention. Uterine prostaglandin secretion peaks earlier (days 11-12) in pregnant pigs than in cyclic pigs, with $\mathrm{PGE}_{2}$ as the predominant prostaglandin (Christenson et al., 1994). Intrauterine infusion of $\mathrm{PGE}_{2}$ lengthens the lifespan of corpora lutea (Akinlosotu et al., 1986), and intraluteal administration (Ford and Christenson, 1991) or intrauterine infusion (Akinlosotu et al., 1988) of $\mathrm{PGE}_{2}$ prevents luteolysis induced by $\mathrm{PGF}_{2 \omega^{*}}$ In addition, $\mathrm{PGE}_{2}$ stimulates progesterone production by luteal cells from gilts at day 12 of the oestrous cycle and during early pregnancy (Wiesak et al., 1992). Therefore, $\mathrm{PGE}_{2}$ is often considered luteotrophic and important in the function of the pig corpus luteum during the establishment of pregnancy.

The corpora lutea of pigs contain small (SLC) and large luteal cells (LLC) (Lemon and Loir, 1977). Pig SLC and LLC, collected on days $8-9$ of the oestrous cycle, have been shown to be

*Correspondence.

Received 23 July 1997. regulated in different ways by $\mathrm{LH}$ and $\mathrm{PGE}_{2}$ (Richards et al., 1994). LH was found to stimulate progesterone secretion by SLC but not by LLC. Conversely, $\mathrm{PGE}_{2}$ stimulates progesterone secretion by LLC, but not by SLC (Richards et al., 1994). However, there is conflicting data concerning the effects of $\mathrm{LH}$ on progesterone production by SLC and LLC. The confusion is exemplified by the observations that LH stimulated SLC, LLC or both (Hunter, 1981; Buhr, 1987; Tekpetey and Armstrong, 1991; Yuan et al., 1993; Wiesak et al., 1994). Despite the apparent stimulatory effects of LH on LLC, LH receptors have been found only on SLC (Meduri et al., 1992, 1996). In contrast, PGE receptors are present primarily on LLC (Feng and Almond, 1996).

It has been suggested that cAMP mediates $\mathrm{LH}$-induced progesterone secretion by pig SLC (Tekpetey and Armstrong, 1991; Richards and Almond, 1994) and $\mathrm{PGE}_{2}$-stimulated progesterone secretion by luteinized granulosa cells (Grimes et al., 1993). The present study was designed to examine further the differential effects of LH and PGE 2 on pig SLC and LLC during the oestrous cycle and early pregnancy. In addition, 8-bromocAMP and forskolin were included to evaluate the potential role of cAMP in $\mathrm{PGE}_{2}$-stimulated progesterone secretion by LLC. 


\section{Materials and Methods}

\section{Materials}

Hank's Balanced Salt Solution (HBSS; without calcium and magnesium), Hepes, sodium bicarbonate, $\mathrm{PGE}_{2}$, forskolin, 8-bromo-adenosine $3^{\prime}, 5^{\prime}$ cyclic monophosphate (8-bromocAMP), DNase (type I from bovine pancreas), hyaluronidase (type V from ovine testis), BSA (fraction V), Tris, penicillinstreptomycin and gentamicin were obtained from Sigma Chemical Co. (St Louis, MO). Pig LH (LER 786-3) was supplied by L E Reichert, Ir (Albany, NY). Collagenase (type IV) was purchased from Worthington Biochemical Corporation (Freehold, NJ). The Coat-a-Count progesterone radioimmunoassay kits were purchased from Diagnostic Products Corporation (Los Angeles, CA).

\section{Animals and collection of ovaries}

Twenty-nine gilts (6-7 months old) were obtained and housed at the North Carolina State University Swine Education and Research Facility. The onset of oestrus was detected by daily exposure to a mature boar. The first day of standing oestrus was considered day 0 of the oestrous cycle. Fifteen gilts were mated twice by artificial insemination beginning on the day after the onset of oestrus. The first day of insemination was considered day $I$ of pregnancy. The experimental protocol was approved by the Institutional Animal Care and Use Committee of North Carolina State University.

Animals were killed by intravenous injections with Beuthanasia-D special $\left(58.5 \mathrm{mg}\right.$ pentobarbital sodium $\mathrm{kg}^{-1}$ and $7.5 \mathrm{mg}$ phenytoin sodium $\mathrm{kg}^{-1}$; Schering-Plough Animal Health Corporation, Kenilworth, NJ) and the ovaries collected immediately, aseptically. Ovaries were collected from animals on day 9 ( $n=$ five gilts), day 12 ( $n=$ three gilts), and day 14 ( $n=$ six gilts) of the oestrous cycle and day 9 ( $n=$ four gilts), day $12(n=$ four gilts), day 14 ( $n=$ four gilts) and day $30(n=$ three gilts) of pregnancy. The corpora lutea from three of six nonmated gilts (day 14) were white and non-vascular. These corpora lutea were not used owing to the small numbers of LLC obtained after enzyme dissociation. The corpora lutea from the other three gilts, at day 14 of the oestrous cycle, were red and vascular and were used in this study. Uteri were removed and flushed with PBS (day 9, 12 and 14 pregnant gilts) or incised (gilts at day 30 of pregnancy) to confirm the presence of conceptuses. Immediately after removal from the animals, the ovaries were transported to the laboratory in

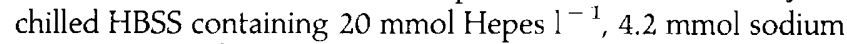
bicarbonate $\mathrm{l}^{-1}, 100 \mathrm{U}$ penicillin $\mathrm{ml}^{-1}, 100 \mu \mathrm{g}$ streptomycin $\mathrm{ml}^{-1}$ and $50 \mu \mathrm{g}$ gentamicin $\mathrm{ml}^{-1}$. The number of corpora lutea per gilt was $13.6 \pm 0.7$ (mean $\pm \mathrm{SEM}, n=26$ gilts).

A blood sample was collected from each animal before death. This sample was used to determine serum progesterone concentrations. Blood was allowed to clot at room temperature before centrifugation $(800 \mathrm{~g}, 30 \mathrm{~min})$ to collect serum. Serum samples were stored at $-20^{\circ} \mathrm{C}$ until assayed for progesterone concentrations.

\section{Dissociation of corpora lutea}

Corpora lutea were dissected from the ovaries and dissociated by collagenase (type IV, 60 units $^{\mathrm{mg}^{-1}}$ dry weight) and hyaluronidase to obtain dispersed luteal cells as reported by Richards et al. (1994). Viability of dissociated luteal cells was greater than $80 \%$ as determined by Trypan blue exclusion.

\section{Preparation of small and large cells}

Small and large cells were isolated by elutriation (Gadsby et al., 1990; Richards et al., 1994), immediately after cell dispersal. Dissociated luteal cells were elutriated using HBSS containing $20 \mathrm{mmol}$ Hepes $\mathrm{I}^{-1}, 4.2 \mathrm{mmol}$ sodium bicarbonate $1^{-1}, 1 \mathrm{mg} \mathrm{BSA} \mathrm{ml} l^{-1}, 0.02 \mathrm{mg}^{-1 N a s e ~ \mathrm{ml}^{-1}}, 100 \mathrm{U}$ penicillin $\mathrm{ml}^{-1}, 100 \mu \mathrm{g}$ streptomycin $\mathrm{ml}^{-1}$ and $50 \mu \mathrm{g}$ gentamicin $\mathrm{ml}^{-1}$. Five fractions ( $200 \mathrm{ml}$ per fraction) were collected in succession at buffer flows of $12 \mathrm{ml} \mathrm{min}^{-1}$ at $1360 \mathrm{~g}, 24 \mathrm{mI} \mathrm{min}{ }^{-1}$ at $1360 \mathrm{~g}, 30 \mathrm{ml} \mathrm{min}^{-1}$ at $1360 \mathrm{~g}, 30 \mathrm{ml} \mathrm{min}{ }^{-1}$ at $1020 \mathrm{~g}$ and $30 \mathrm{ml} \mathrm{min}{ }^{-1}$ at $680 \mathrm{~g}$. A sample from each fraction was examined with light microscopy. The first fraction contained mainly erythrocytes. The second fraction contained only small cells $(<23 \mu \mathrm{m}$ in diameter), while the third and fourth fractions contained small cells, small cell clumps and large cells. The fifth fraction contained large cells ( $>23 \mu \mathrm{m}$ in diameter) and $8.6 \pm 1 \%$ small cells $(n=26$ pigs). Viabilities of small (fraction 2 ) and large cells (fraction 5) were greater than $85 \%$.

\section{Cell culture and treatments}

Cell cultures were performed using established procedures (Richards et al., 1994). Incubation media was medium 199 containing $20 \mathrm{mmol}$ Hepes $\mathrm{l}^{-1}, 4.2 \mathrm{mmol} \mathrm{NaHCO} 3 \mathrm{l}^{-1}, 5 \mu \mathrm{g}$ insulin $\mathrm{ml}^{-1}, 40 \mathrm{ng}$ hydrocortisol $\mathrm{ml}^{-1}, 50 \mu \mathrm{g}$ low-density lipoprotein (LDL)-carried cholesterol $\mathrm{mL}^{-1}, 0.1 \% \mathrm{BSA}, 50 \mu \mathrm{g}$ gentamicin ml ${ }^{-1}, 100 \mathrm{U}$ penicillin $\mathrm{ml}^{-1}$ and $100 \mu \mathrm{g}$ streptomycin $\mathrm{ml}^{-1}, \mathrm{pH} 7.38$. The LDL was prepared as described by Richards et al. (1994). The dissociation and elutriation procedures typically produce a mixed cell fraction with $15 \%$ LLC and 85\% SLC (Feng and Almond, 1996). Therefore, fivefold more SLC than LLC were used in each culture well. The SLC (150000 SLC) or LLC (30000 LLC) were seeded in 24-well plates with $1 \mathrm{ml}$ incubation media per well in the absence or presence of $50 \mathrm{ng} \mathrm{LH} \mathrm{ml}{ }^{-1}, 100 \mathrm{ng} \mathrm{PGE}_{2} \mathrm{ml}^{-1}, 50 \mathrm{ng} \mathrm{LH}$ $\mathrm{ml}^{-1}$ plus $100 \mathrm{ng} \mathrm{PGE}_{2} \mathrm{ml}^{-1}, 0.01,0.1,1 \mathrm{mmol}$ 8-bromocAMP $\mathrm{I}^{-1}$ or $0.5,5,50 \mu \mathrm{mol}$ forskolin $\mathrm{I}^{-1}$ in triplicate wells. Incubations were at $37^{\circ} \mathrm{C}$ with $5 \% \mathrm{CO}_{2}$ in a humid environment for $12 \mathrm{~h}$. Cell viability did not change after $12 \mathrm{~h}$ of culture.

\section{Progesterone radioimmunoassay}

Commercial radioimmunoassay kits, validated for pig serum (Almond and Dial, 1990; Richards and Almond, 1994), were used to determine serum progesterone concentrations. The assay requires no extraction. The progesterone concentration in each serum sample was determined in triplicate and $100 \mu \mathrm{l}$ serum was used in each replicate. The intra-assay coefficients of variation $(\mathrm{CV})$ for both high $\left(24 \mathrm{ng} \mathrm{ml}^{-1}\right)$ and low $\left(4 \mathrm{ng} \mathrm{ml}^{-1}\right)$ progesterone reference sera were $<5 \%$. Sensitivity of the progesterone radioimmunoassay was $10 \mathrm{pg}$ per tube.

For each treatment and day, progesterone production by SLC and LLC was determined independently for cyclic animals 
and pregnant animals. Within day, the cells from pregnant and cyclic animals were not combined. Culture medium was collected from luteal cell incubations and centrifuged at $250 \mathrm{~g}$ for $7 \mathrm{~min}$. After centrifugation, the supernatant was decanted and stored at $-20^{\circ} \mathrm{C}$ until assayed. Progesterone concentrations in the decanted media were determined using established radioimmunoassay procedures (Richards et al., 1994). The intra-assay $\mathrm{CV}$ for high (10.5 $\left.\mathrm{ng} \mathrm{ml}^{-1}\right)$ and low $\left(0.3 \mathrm{ng} \mathrm{m}^{-1}\right)$ progesterone reference media were $6.4 \%$ and $8.9 \%$, respectively. The interassay $\mathrm{CV}$ value was $5.8 \%$ for the high progesterone reference media and $8.2 \%$ for the low media. Sensitivity of the radioimmunoassay was $10 \mathrm{pg}$ per tube.

\section{Statistical analyses}

Differences in serum progesterone concentrations during the oestrous cycle and early pregnancy were analysed by leastsquares analysis of variance (ANOVA) using the General Linear Model (GLM) procedure (SAS, 1988). Effects included in the model were pregnancy status (cyclic versus pregnant), day and their interaction. The difference of serum progesterone concentrations between the cyclic and pregnant gilts within day was detected by contrasts (SAS, 1988).

The mean progesterone concentration in the culture medium from triplicate wells was used for the statistical analysis. The statistical analysis was performed separately for small and large cells to test the effect of each secretagogue on progesterone secretion during the oestrous cycle and early pregnancy. In both cases, the same split-plot design was used. Pregnancy status (cyclic versus pregnant), day and their interaction were included as whole plot effects. Treatment was included as a split-plot effect. Natural log transformation of data was used based on a normal distribution test (Shapiro-Wilks W-test, SAS, 1988) and homogeneous variance test (Barlett's test) (JMP, 1989). The variance of the data from different days of the oestrous cycle and pregnancy, including day 30 of pregnancy, were homogeneous after transformation. Transformed data were subjected to least-squares ANOVA using the GLM procedure (SAS, 1988). The variation between pigs within each whole plot was used as the error term to test the significance of whole plot effect. The mean square of error from the model was used to test the significance of treatment and interaction of treatment with whole plot effects. Differences in progesterone production by SLC or LLC between treatment and control within day were compared by contrasts (SAS, 1988). The means of basal progesterone secretion by SLC or LLC collected at different stages of the oestrous cycle and early pregnancy were compared by least significance difference (SAS, 1988).

\section{Results}

Day, and interaction of day with pregnancy status $(P<0.05)$, but not pregnancy status $(P>0.05)$ affected serum progesterone concentrations (Fig. 1). On day 14, serum progesterone concentrations were lower $(P<0.05)$ in cyclic gilts than in pregnant gilts. Serum progesterone concentrations in the three gilts with white, non-vascular corpora lutea on day 14 were not included in the analysis.

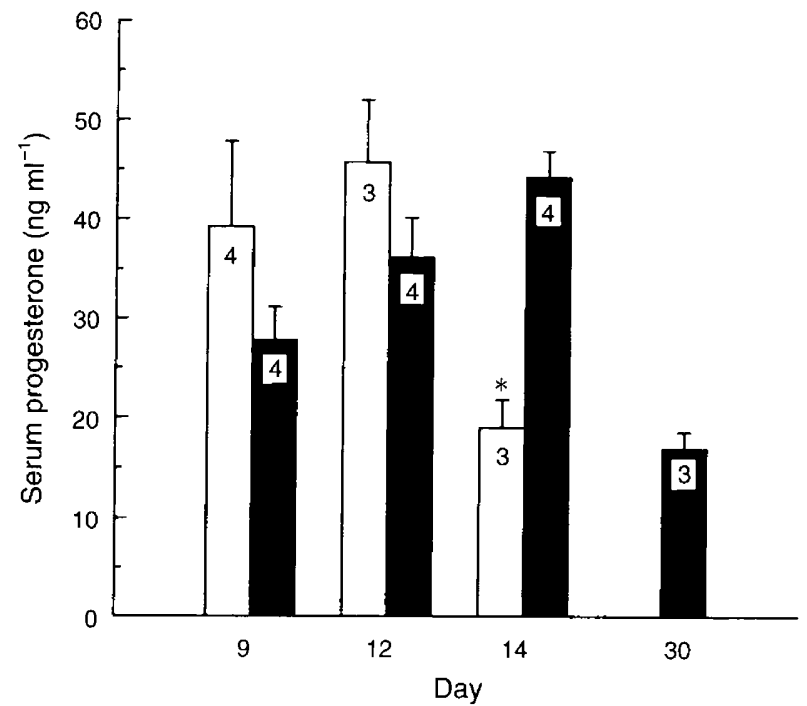

Fig. 1. Serum progesterone concentrations (means + SEM) in ( $\square$ ) cyclic (days 9,12 and 14) and (ם) pregnant gilts (days 9, 12, 14 and 30). The first day of standing oestrus was designated day 0 of the oestrous cycle or pregnancy. The number in each bar represents the number of gilts. Day and interaction of day with pregnancy status but not pregnancy status affected $(P<0.05)$ serum progesterone concentrations. *Indicates that cyclic and pregnant groups differed significantly $(P<0.05)$ within day.

Day, treatment, and the interaction of day with treatment affected $(P<0.001)$ the secretion of progesterone by SLC and LLC. Pregnancy status and other interactions had no effect $(P>0.05)$ on progesterone secretion by SLC or LLC. Thus, the results for progesterone production by SLC or LLC from both cyclic and pregnant gilts were combined.

Basal progesterone secretion by SLC collected at days 14 and 30 was lower $(P<0.05)$ compared with days 9 and 12 after oestrus. Progesterone secretion by SLC collected on days 9 and 12 was stimulated $(P<0.05)$ by LH, PGE 2 , LH plus $\mathrm{PGE}_{2}$, 8 -bromo-cAMP and forskolin (Fig. 2). Stimulation of progesterone secretion by 8-bromo-cAMP or forskolin on day 9 and by 8-bromo-cAMP on day 12 was dose-dependent (linearly, $P<0.05)$. LH, PGE 2,8 -bromo-cAMP and forskolin had no effects on progesterone secretion by SLC collected on days 14 and 30 after oestrus (Fig. 2).

Basal progesterone secretion by LLC was similar between days 9,12 and 14. However, progesterone secretion was lower $(P<0.05)$ by LLC collected at day 30 than by LLC at previous days. $\mathrm{PGE}_{2}$ and $\mathrm{PGE}_{2}$ plus LH stimulated $(P<0.05)$ progesterone secretion by LLC at all stages examined (Fig. 3). LH inhibited $(P<0.05)$ progesterone secretion by LLC at day 14 after oestrus, but had no effect on LLC at other days. Neither 8-bromo-cAMP nor forskolin altered progesterone secretion by LLC collected on day 9; however, 8-bromo-cAMP and forskolin inhibited $(P<0.05)$ progesterone secretion by LLC from day 12 gilts. Both 8-bromo-cAMP and forskolin further inhibited $(P<0.001)$ progesterone production by LLC collected from day 14 gilts. 8-Bromo-cAMP had a linear and quadratic dose-effect, and forskolin had a linear dose-effect $(P<0.05)$. On day 30 of pregnancy, 8-bromo-cAMP $(0.1$ and $1 \mathrm{mmol}$ $\left.\mathrm{l}^{-1}\right)$ and forskolin $\left(5 \mu \mathrm{mol} \mathrm{l} \mathrm{l}^{-1}\right)$ stimulated $(P<0.05)$ progesterone secretion by LLC (Fig. 3). 


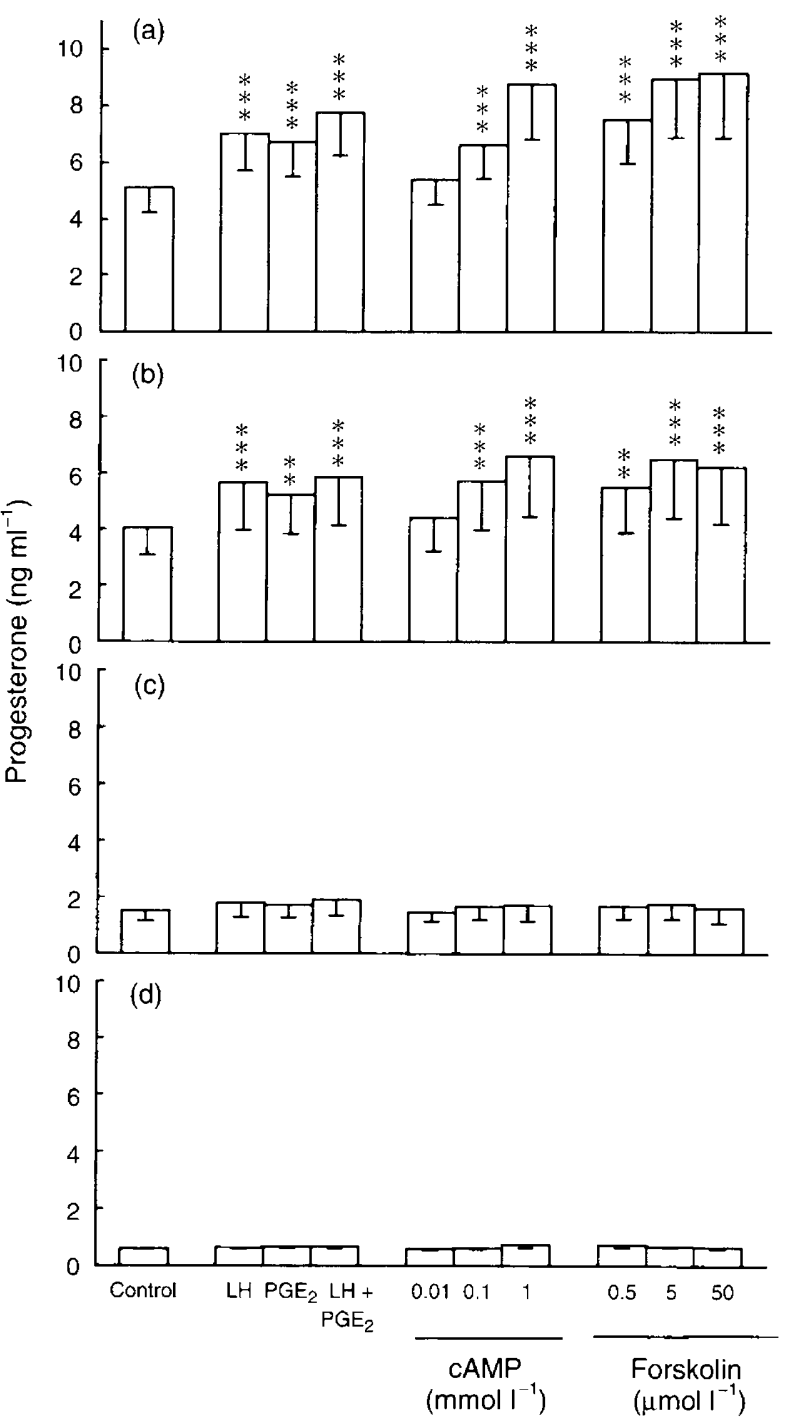

Fig. 2. Progesterone secretion (means - SEM) by small luteal cells (SLC) collected on (a) day 9, (b) day 12, (c) day 14 and (d) day 30 after oestrus. SLC from cyclic and pregnant gilts were cultured for $12 \mathrm{~h}$ in the absence (control) or presence of $50 \mathrm{ng} \mathrm{LH} \mathrm{ml}^{-1}, 100 \mathrm{ng}$ prostaglandin $\mathrm{E}_{2}\left(\mathrm{PGE}_{2}\right) \mathrm{ml}^{-1}, 50 \mathrm{ng} \mathrm{LH} \mathrm{ml} \mathrm{H}^{-1}$ plus $100 \mathrm{ng} \mathrm{PGE}_{2} \mathrm{ml}^{-\mathrm{I}}$, $0.01,0.1,1 \mathrm{mmol}$ 8-bromo-cAMP (cAMP) $1^{-1}$ or $0.5,5,50 \mu \mathrm{mol}$ forskolin $\mathrm{I}^{-1}$. Within day, ${ }^{* *}$ and $* * *$ indicate differences of $P<0.01$, and $P<0.001$, respectively, compared with basal progesterone production by control SLC.

\section{Discussion}

By day 14, SLC had lost their responsiveness to the hormones and basal progesterone secretion had decreased by this time. Forskolin and 8-bromo-cAMP inhibited progesterone secretion by LLC on days 12 and 14 , although basal progesterone production did not change. These data suggest that pig luteal cells change markedly around days 12 and 14 . Correspondingly, pig corpora lutea become sensitive to the luteolytic effect of PGF $_{2 \alpha}$ after day 12 of the oestrous cycle (Gleeson, 1974; Diehl and Day, 1974) and maternal recognition of pregnancy occurs during this interval (Bazer et al., 1992). However, little information is available about the intracellular
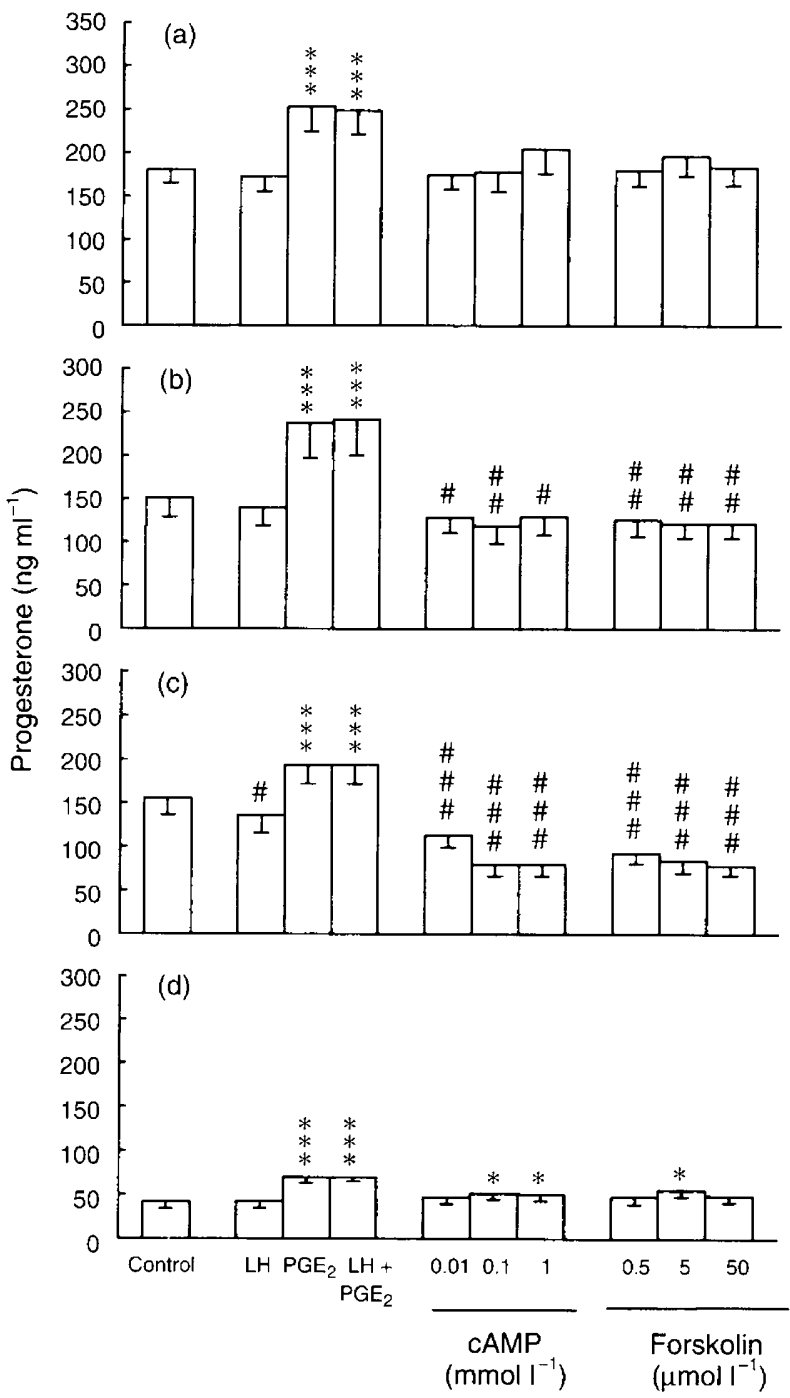

Fig. 3. Progesterone secretion (means - SEM) by large luteal cells (LLC) collected on (a) day 9, (b) day 12, (c) day 14 and (d) day 30 after oestrus. LLC from cyclic and pregnant gilts were cultured for $12 \mathrm{~h}$ in the absence (control) or presence of $50 \mathrm{ng} \mathrm{LH} \mathrm{ml}^{-1}, 100 \mathrm{ng}$ prostaglandin $\mathrm{E}_{2}\left(\mathrm{PGE}_{2}\right) \mathrm{ml}^{-1}, 50 \mathrm{ng} \mathrm{LH} \mathrm{ml}{ }^{-1}$ plus $100 \mathrm{ng} \mathrm{PGE}_{2} \mathrm{ml}^{-1}$, $0.01,0.1,1 \mathrm{mmol} 8$-bromo-cAMP (cAMP) $1^{-1}$ or $0.5,5,50 \mu \mathrm{mol}$ forskolin $1^{-1}$. Within day, $*, * *$ and $* * *$ indicate stimulation at

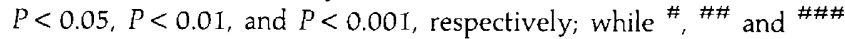
indicate inhibition at $P<0.05, P<0.01$, and $P<0.001$, respectively, compared with basal progesterone production by control LLC.

changes during this stage of pregnancy or the oestrous cycle. Unexpectedly, pregnancy status and the interaction of pregnancy status with treatment had no effect on progesterone secretion by cultured SLC or LLC collected on day 14, even though the concentrations of serum progesterone declined in cyclic, but not in pregnant, animals. It is possible that the collection of corpora lutea for in vitro studies removes, or reduces, the effects of endogenous hormones on progesterone production by luteal cells. At days 12-14 in cyclic pigs, concentrations of $\mathrm{PGF}_{2 u}$ are higher in the utero-ovarian vein compared with those of $\mathrm{PGE}_{2}$. Conversely, $\mathrm{PGE}_{2}$ concentrations are higher than $\mathrm{PGF}_{2 \alpha}$ concentrations in utero-ovarian veins of pregnant pigs (Christenson et al., 1994). Therefore, 
differences observed in serum progesterone concentrations reflect the influence of endogenous hormones; however, the functional status of luteal cells from cyclic and pregnant gilts appears to be similar under in vitro conditions.

The results of the present study indicate that $\mathrm{LH}$ and $\mathrm{PGE}_{2}$ act via different second message pathways in SLC and LLC. The results also confirm previous reports (Tekpetey and Armstrong, 1991; Richards et al., 1994) that showed that 8-bromo-cAMP and forskolin stimulate progesterone secretion by pig SLC in a similar fashion to LH. This observation suggests that cAMP mediates LH-induced progesterone secretion as previously demonstrated in ovine corpora lutea (Hoyer and Niswender, 1986). Four PGE receptor subtypes, $\mathrm{EP}_{1}, \mathrm{EP}_{2}$, $\mathrm{EP}_{3}$ and $\mathrm{EP}_{4}$, have been identified and cloned from various tissues and species (Coleman et al., 1994; Regan et al., 1994; Katsuyama et al., 1995; Negishi et al., 1995). EP 1 couples to an unidentified $G$ protein to increase intracellular $\mathrm{Ca}^{2+} . \mathrm{EP}_{2}$ and $\mathrm{EP}_{4}$ couple to $\mathrm{Gs}$ to increase cAMP, whereas $\mathrm{EP}_{3}$ couples to $\mathrm{Gi}$, $\mathrm{Gs}$ or $\mathrm{Gq}$ to increase cAMP, decrease cAMP or activate the phospholipase $C$ pathway, respectively, depending on the isoform of the receptor (Coleman et al., 1994). The present results show that 8-bromo-cAMP and forskolin inhibit progesterone production by LLC collected on days 12 and 14 . These data suggest that $\mathrm{PGE}_{2}$ does not act by increasing $\mathrm{CAMP}$ and that the receptor subtype may not be $\mathrm{EP}_{2}$ and $\mathrm{EP}_{4}$ in pig LLC. $\mathrm{EP}_{3}$ receptors have been demonstrated in ovine (Pierce et al., 1995) and bovine (Anderson and Wiltbank, 1995) corpora lutea. It is of interest that pig LLC differ from the luteinized granulosa cells that produce cAMP in response to $\mathrm{PGE}_{2}$ and that $\mathrm{PGE}_{2}$ acts like cAMP to enhance progesterone production (Grimes et al., 1993).

The protein kinase $C$ pathway is another signal transduction pathway in luteal cells. Protein kinase $C$ activity increases nearly threefold in mature corpora lutea relative to postovulatory follicles (DeManno et al., 1992). In a short $(4 \mathrm{~h})$ culture without LDL, phorbol-12 myristate-13 acetate, a potent stimulant of the protein kinase $C$ pathway, induced progesterone secretion by pig LLC (Gadsby and Earnest, 1994). However, after $24 \mathrm{~h}$ culture, activation of protein kinase $\mathrm{C}$ inhibited progesterone production by pig mixed luteal cells in the presence of LDL (Brannian et al., 1995). Further studies are needed to elucidate the intracellular signal pathway for $\mathrm{PGE}_{2}-$ stimulated progesterone production by LLC.

The present study also showed that 8-bromo-cAMP and forskolin inhibited progesterone production by LLC collected on days 12 and 14 . The mechanism of this inhibition is not clear. One possibility is that 8-bromo-cAMP and forskolin induced apoptosis. Although the viability of LLC collected on days $12-14$ did not change after $12 \mathrm{~h}$ culture, apoptosis may already be in progress. Aharoni et al. (1995) reported that cAMP and forskolin stimulated rat granulosa cell differentiation to luteal cells, with an initial increase in progesterone secretion, followed by apoptosis and suppression of progesterone secretion. Forskolin and 8-bromo-cAMP may induce or hasten apoptosis in the LLC collected from gilts at days 12 and 14 , with a subsequent decrease in progesterone production.

A previous study by Tekpetey and Armstrong (1991) reported that dbcAMP and forskolin had no effect on progesterone secretion by LLC. The age of the corpora lutea was considered as mid-cycle (days 12-14) based on the morpho- logical appearance of the samples collected at an abattoir. In the present study, days 9-12 appeared to be mid-cycle and day 14 as late-cycle, since the corpora lutea collected from half of the day 14 pigs were non-vascular and white. It is possible that hormones that stimulate cAMP production stimulate the growth of follicles and at the same time enhance regression of aged corpora lutea, and specifically the LLC. This suggestion is supported by our observation that $\mathrm{LH}$ inhibited progesterone secretion by LLC collected on day 14 and FSH inhibited progesterone secretion by LLC collected on day 15 but not by those collected on day 10 (Yuan et al., 1993). It is well known that $\mathrm{LH}$ and FSH act by increasing CAMP production.

Conflicting data exist on the role of $\mathrm{LH}$ in the pig corpora lutea. At mid-cycle, LH stimulates progesterone secretion by SLC, but has no, or minimal, effect on progesterone secretion by LLC (Hunter, 1981; Tekpetey and Armstrong, 1991; Richards et al., 1994). Wiesak et al. (1994) showed that LH stimulated progesterone production by LLC, but not by SLC. LH has no effect (Buhr, 1987) or induces similar, albeit minimal, progesterone production by both SLC and LLC (Yuan et al., 1993). The reason for these discrepancies was discussed by Richards et al. (1994). In spite of these differences, the aforementioned studies reveal that LH stimulation of progesterone secretion by pig luteal cells is less than twofold, which is lower than the stimulatory effects of LH on ovine luteal cells (twoto fortyfold) (Niswender et al., 1994). Hypophysectomy (Anderson and Melampy, 1967) or administration of LH antiserum (Spies $e$ al., 1967) after the preovulatory surge of LH did not interrupt subsequent function of the corpora lutea. The results of the present study showed that LH stimulated progesterone production by SLC collected on days 9 and 12 , but had no effect on production by SLC collected at days 14 and 30. In addition, LH had an inhibitory effect on production by LLC collected on day 14 . Similarly, it has been reported that LH has no effect on progesterone production by pig SLC and LLC at day 15 of the oestrous cycle after $24 \mathrm{~h}$ culture (Buhr, 1987; Yuan et al., 1993). However, progesterone secretion was acutely stimulated when pig SLC, collected from sows on day 30 and day 60 of pregnancy, were superfused with a high dose of $\mathrm{LH}(10 \mu \mathrm{g}$ in $3 \mathrm{ml}$ ) (Lemon and Loir, 1977). Anderson (1987) also found that $\mathrm{LH}$ is required from about day 14 to day 50 of pregnancy. The concentration of $\mathrm{LH}$ receptors on pig corpora lutea increases from early to mid-cycle (day 10), and decreases after day 12 of the oestrous cycle. Concentrations of LH receptors also increase between days 12 and 30 of pregnancy; however, the affinity of the receptor decreases at day 30 of pregnancy (Ziecik et al., 1980). L.H receptors exist only on SLC (Meduri et al., 1992, 1996). Furthermore, the activity of adenylate cyclase, which is presumably involved in LH signal transduction in corpora lutea, increases from day 3 to day 8 , and then decreases on day 13 of the pig oestrous cycle (Ritzhaupt et al., 1986). Overall, the results of the present study and previous investigations suggest that $\mathrm{LH}$ has a moderate stimulatory role on SLC at mid-cycle, but that progesterone production by LLC is independent of LH.

Richards et al. (1994) reported that $\mathrm{PGE}_{2}$ increases progesterone secretion by pig LLC but not SLC. In the present study, $\mathrm{PGE}_{2}$ had a moderate stimulatory effect on progesterone secretion by pig SLC on days 9 and 12, while $\mathrm{PGE}_{2}$ stimulated progesterone secretion by LLC at all stages examined. The 
same in vitro culture system was used in the two studies. However, the previous study used prepubertal gilts and oestrus was induced by PG-600 ${ }^{\mathrm{R}}$ (400 iu eCG and $200 \mathrm{iu}$ hCG; Intervet, Millsboro, DE), while the present study used postpubertal, naturally cyclic gilts, which could contribute to some of the differences observed in the two studies. PGE receptors were sixtyfold more abundant on LLC than on SLC in pigs (Feng and Almond, 1996). Taken together, these data suggest the primary targets of $\mathrm{PGE}_{2}$ are LLC.

The present study showed that progesterone secretion by SLC or LLC was less at day 30 of pregnancy than at days 9 and 12 after oestrus. Wiesak et al. (1994) found that mixed luteal cells from pigs at day 16 of pregnancy released less progesterone than did cells from pigs at day 12 of pregnancy or of the oestrous cycle. Thus, peripheral progesterone concentrations have consistently been found to decline on day 30 of pregnancy compared with day 10 (Bazer et al., 1982) or with days 9-14 (present study).

In summary, day, treatment and interaction of day with treatment, but not pregnancy status and other interactions affected progesterone production by SLC and LLC in response to secretagogues before day 14 of the oestrous cycle or of pregnancy. These data demonstrate that SLC and LLC are regulated in different ways during the oestrous cycle and early pregnancy and suggest that $\mathrm{PGE}_{2}$ does not act by increasing cAMP in pig LLC.

The authors gratefully acknowledge the technical assistance of P. A. Routh and W. Hevener and thank J. Jayawickrama for her assistance with statistical analysis of data, and R. G. Richards, J. E. Gadsby and W. Tompkins for their advice and comments. This work was supported by the North Carolina Veterinary Competitive Grants Program.

\section{References}

Aharoni D, Dantes A, Oren M and Amsterdam A (1995) cAMP-mediated signals as determinants for apoptosis in primary granulosa cells Experimental Cell Research 218 271-282

Akinlosotu BA, Diehl JR and Gimenez T (1986) Sparing effects of intrauterine treatment with prostaglandin $\mathrm{E}_{2}$ on luteal function in cycling gilts Prostaglandins 32 291-299

Akinlosotu BA, Diehl JR and Gimenez T (1988) Prostaglandin E, counteracts the effects of $\mathrm{PGF}_{2 \pi}$ in indomethacin treated cycling gilts Prostaglandins 35 $81-93$

Almond GW and Dial GD (1990) Steroid hormone and luteinizing hormone concentrations in the anestrous sow Canadian Journal of Veterinary Research $54209-214$

Anderson LE and Wiltbank MC (1995) Specificity of prostaglandin binding in bovine corpora luteal plasma membrane Biology of Reproduction 52 (Supplement 1) 109 (Abstract)

Anderson LL (1987) Regulation of Ovarian and Testicular Function pp 421-463 Eds VB Mahesh, VB Dhindsa, E Anderson and SP Kalra. Plenum Press, New York

Anderson LL and Melampy RM (1967) Hypophysial and uterine influences on pig luteal function. In Reproduction in the Female Mammal pp 75-78 Eds GE Lamming and EC Amoroso. Butterworths, London

Bazer FW, Geisert RD, Thatcher WW and Roberts RM (1982) The establishment and maintenance of pregnancy. In Control of Pig Reproduction pp 227-252 Eds DJA Cole and GR Foxcroft. Butterworths, London

Bazer FW, Mirando MA, Ott TL, Harney JP, Dubois DH, Schalue TK, Pontzer CH, Hostetler C, Johnson HM and Ogle T (1992) Roles of ovine trophoblast protein 1 and oestradiol/prolactin in the establishment of pregnancy in sheep and pigs Reproduction, Fertility and Development 4 335-340

Brannian JD, Christianson H, Flynn S and Kurz SG (1995) Loss of low-density lipoprotein utilization by regressing porcine luteal cells: effects of protein kinase C activation Biology of Reproduction 52 793-797
Buhr MM (1987) Effect of lipoproteins and luteinizing hormone on progesterone production by large and small luteal cells throughout the porcine estrous cycle Journal of Animal Science 65 1027-1033

Christenson LK, Farley DB, Anderson LH and Ford SP (1994) Luteal maintenance during early pregnancy in the pig: role for prostaglandin $\mathrm{E}_{2}$ Prostaglandins 47 61-75

Coleman RA, Smith WL and Narumiya S (1994) International Union of Pharmacology classification of prostanoid receptors: properties, distribution, and structure of the receptors and their subtypes Pharmacological Reviews 46 205-229

DeManno DA, Maizels ET and Hunzicker-Dunn M (1992) Hormonal regulation of the type III isoform of C-kinase in porcine ovarian tissues Molecular and Cellular Endocrinology 86 157-166

Diehl JR and Day BN (1974) Effect of prostaglandin $\mathrm{F}_{2, a}$ on luteal function in swine Journal of Animal Science 39 392-396

Feng SM and Almond GW (1996) Identification and distribution of prostaglandin E receptors on porcine luteal cells Biology of Reproduction $\mathbf{5 4}$ 1366-1374

Ford SP and Christenson LK (1991) Direct effects of oestradiol-17 $\beta$ and prostaglandin $E_{2}$ in protecting pig corpora lutea from a luteolytic dose of prostaglandin $\mathrm{F}_{2 \alpha}$ Journal of Reproduction and Fertility 93 203-209

Gadsby JE and Earnest KL (1994) Prostaglandin $\mathrm{F}_{2 a}$ stimulates progesterone secretion by porcine luteal cells in vitro throughout the estrous cycle Prostaglandins 48 109-125

Gadsby JE, Balapure AK, Britt JH and Fitz TA (1990) Prostaglandin $\mathrm{F}_{2 u}$ receptors on enzyme-dissociated pig luteal cells throughout the estrous cycle Endocrinology 126 787-795

Gleeson AR (1974) Proceedings: luteal function in the cyclic sow after infusion of prostaglandin $\mathrm{F}_{2 u}$ through a uterine vein Journal of Reproduction and Fertility $36487-488$

Grimes RW, Samaras SE and Hammond JM (1993) Divergent actions of prostaglandins $-\mathrm{E}_{2}$ and $-\mathrm{F}_{2 \alpha}$ on the regulation of insulin-like growth factorbinding protein-3 in luteinized granulosa cells Endocrinology 132 I414-1416

Hoyer PB and Niswender GD (1986) Adenosine 3',5'-monophosphate-binding capacity in small and large ovine luteal cells Endocrinology 119 1822-1829

Hunter MG (1981) Responsiveness in vitro of porcine luteal tissue recovered at two stages of the luteal phase Journal of Reproduction and Fertility 63 471-476

JMP (1989) JMP User's Guide Version 2 pp 285-288 Statistical Analysis System Institute Inc, Cary, NC

Katsuyama M, Nishigaki N, Sugimoto $Y$, Morimoto K, Negishi M, Narumiya $S$ and Ichikawa $A$ (1995) The mouse prostaglandin $E$ receptor $\mathrm{EP}_{2}$ subtype: cloning, expression, and northern blot analysis FEBS Letters 372 151 -156

Lemon M and Loir M (1977) Steroid release in vitro by two luteal cell types in the corpus luteum of the pregnant sow Journal of Endocrinology 72 351-359

Meduri G, Vuhai-Luuthi MT, Jolivet A and Milgrom E (1992) New functional zonation in the ovary as shown by immunohistochemistry of luteinizing hormone receptor Endocrinology 131 366-373

Meduri G, Vu Hai MT, Jolivet A, Takemori S, Kominami S, Driancourt MA and Milgrom E (1996) Comparison of cellular distribution of LH receptors and steroidogenic enzymes in the porcine ovary Journal of Endocrinology 148 $435-446$

Negishi M, Sugimoto $Y$ and Ichikawa A (1995) Molecular mechanisms of diverse actions of prostanoid receptors Biochimica et Biophysica Acta 1259 109-119

Niswender GD, Juengel JL, McGuire WJ, BelÆore CJ and Wiltbank MC (1994) Luteal function: the estrous cycle and early pregnancy Biology of Reproduction 50 $239-247$

Pierce KL, Reuda BR, Botros IW, Bailey TJ, Reagan JW and Hoyer PB (1995) Cloning and characterization of a receptor for prostaglandin $E_{2}\left(E_{2}\right)$ from ovine corpora lutea Biology of Reproduction 52 (Supplement 1) Abstract 198

Regan JW, Bailey TJ, Pepperl DJ, Pierce KL, Bogardus AM, Donello JE, Fairbairn CE, Kedzie KM, Woodward DF and Gil DW (1994) Cloning of a novel human prostaglandin receptor with characteristics of the pharmacologically defined $\mathrm{EP}_{2}$ subtype Molecular Pharmacology 46 213-220

Richards RG and Almond GW (1994) Tumour necrosis factor-alpha differentially alters progesterone and prostaglandin $\mathrm{F}_{2 u}$ production by porcine luteal cells Journal of Endocrinology 143 75-83

Richards RG, Gadsby JE and Almond GW (1994) Differential effects of LH and $\mathrm{PGE}_{2}$ on progesterone secretion by small and large porcine luteal cells Journal of Reproduction and Fertility 102 27-34

Ritzhaupt LK, Nowak RA, Calvo FO, Khan IM and Bahr JM (1986) Adenylate cyclase activity of the corpus luteum during the oestrous cycle of the pig Journal of Reproduction and Fertility 78 361-366 
SAS (1988) SASISTAT User's Guide (Release 6.03) pp 549-640 Statistical Analysis System Institute Inc, Cary, NC

Spies HG, Slyter AL and Quadri SK (1967) Regression of corpora lutea in pregnant gilts administered antiovine L.H rabbit serum Journal of Animal Science 26 768-771

Tekpetey FR and Armstrong DT (1991) Steroidogenic response of rat and pig luteal cells to estradiol-17 $\beta$ and catecholestrogens in vitro. Biology of Reproduction 45 498-505

Wiesak T, Hunter MG and Foxcroft GR (1992) Effect of prostaglandins on luteal function during early pregnancy in pigs Journal of Reproduction and Fertility 95 $831-840$
Wiesak T, Hardin RT and Foxcroft GR (1994) Evaluation of in vitro culture conditions to demonstrate pregnancy-dependent changes in luteal function in the pig Biology of Reproduction 51 254-261

Yuan W, Connor ML and Buhr MM (1993) Responsiveness of porcine large and small luteal cells to luteotropic or luteolytic hormones and cell morphologic changes during the estrous cycle and pregnancy Journal of Animal Science $\mathbf{7 1}$ 481-491

Ziecik A, Shaw HJ and Flint AP (1980) Luteal LH receptors during the oestrous cycle and early pregnancy in the pig Journal of Reproduction and Fertility 60 129-137 